\title{
Hepatic Differentiation of Stem Cells in 2D and 3D Biomaterial Systems
}

\author{
Xiaoyu Zhao 1,2, Yanlun Zhu ${ }^{1,2}$, Andrew L. Laslett ${ }^{3,4}$ and Hon Fai Chan 1,2,*(D) \\ 1 Institute for Tissue Engineering and Regenerative Medicine, The Chinese University of Hong Kong, \\ Hong Kong 999077, China; xiaoyuzhao@cuhk.edu.hk (X.Z.); 1155136524@link.cuhk.edu.hk (Y.Z.) \\ 2 Key Laboratory for Regenerative Medicine, Ministry of Education, School of Biomedical Sciences, \\ Faculty of Medicine, The Chinese University of Hong Kong, Hong Kong 999077, China \\ 3 CSIRO Manufacturing, Clayton, Victoria 3168, Australia; Andrew.Laslett@csiro.au \\ 4 Australian Regenerative Medicine Institute, Monash University, Victoria 3800, Australia \\ * Correspondence: honfaichan@cuhk.edu.hk; Tel.: +852-39433032
}

Received: 29 April 2020; Accepted: 22 May 2020; Published: 25 May 2020

\begin{abstract}
A critical shortage of donor livers for treating end-stage liver failure signifies the urgent need for alternative treatment options. Hepatocyte-like cells (HLC) derived from various stem cells represent a promising cell source for hepatocyte transplantation, liver tissue engineering, and development of a bioartificial liver assist device. At present, the protocols of hepatic differentiation of stem cells are optimized based on soluble chemical signals introduced in the culture medium and the HLC produced typically retain an immature phenotype. To promote further hepatic differentiation and maturation, biomaterials can be designed to recapitulate cell-extracellular matrix (ECM) interactions in both 2D and 3D configurations. In this review, we will summarize and compare various 2D and 3D biomaterial systems that have been applied to hepatic differentiation, and highlight their roles in presenting biochemical and physical cues to different stem cell sources.
\end{abstract}

Keywords: hepatic differentiation; stem cell; biomaterial; decellularized extracellular matrix; stiffness; topography

\section{Introduction}

Liver, the largest internal organ in our body, performs many important functions including protein synthesis, detoxification, metabolism and bile secretion. The liver has a remarkable capability to regenerate after injury or resection, such as after partial hepatectomy. Nevertheless, in situations such as acute liver injury or end-stage liver disease, liver regeneration is insufficient resulting in liver failure and eventually death [1]. Liver disease accounts for approximately 2 million deaths per year worldwide [2]. The leading causes of liver-associated deaths include liver cirrhosis, viral hepatitis, and hepatocellular carcinoma. In particular, liver cirrhosis and liver cancer are currently the 11th and 16th most common causes of death globally [2]. Together, they account for $3.5 \%$ of all deaths worldwide. Liver transplantation, as the only definite treatment for acute liver failure and end-stage liver disease, is hampered by the limited supply of donor organs [3]. Consequently, alternative treatments are desperately needed to combat severe liver diseases.

Hepatocyte transplantation and tissue engineering are deemed as promising alternatives to liver transplantation. Transplantation of hepatocytes instead of intact liver is advantageous as it is a less invasive procedure and permits the use of cryopreserved cells [4]. On the other hand, tissue engineering combines both cells and scaffolds to develop biological substitutes to restore or replace damaged tissues or organs, and has been used to reconstruct various tissues/organs such as skin, liver, spinal cord and blood vessels for implantation [5]. Hepatocytes and engineered liver 
constructs can also be incorporated in bioartificial liver assist devices to offer temporary support to liver functions [6]. Central to these approaches is the requirement of a sustainable cell source which cannot be met by primary hepatocytes due to a shortage of donor livers. To overcome the shortage of hepatocytes, scientists are actively pursuing the derivation of functional hepatocytes from stem cells, including mesenchymal stem cells (MSC), embryonic stem cells (ESC), induced pluripotent stem cells (iPSC), and hepatic progenitor/stem cells (HPC) [7]. Stem cells are an attractive cell source, characterized by a self-renewal capacity as well as potential to differentiate into diverse cell progenies, including the hepatic lineage. Therefore, hepatocyte-like cells (HLC) differentiated from stem cells, with morphological, phenotypic, and functional characteristics of mature hepatocytes, could potentially be employed in hepatocyte transplantation and liver tissue engineering.

Typically, stem cells are differentiated by introducing various combinations of soluble chemical signals (e.g., growth factors or small molecules) to coax the cells into becoming HLC, usually via a stepwise strategy in 2D or 3D [8]. Monolayer culture is the most common method to induce differentiation, but 3D differentiation involving culturing stem cells such as embryoid bodies or spheroids and encapsulating cells in a scaffold has also been reported [9]. Although a number of reports have attempted to optimize the differentiation protocol in terms of differentiation efficiency and cost, the HLC produced are mostly immature in nature (i.e., expressing early hepatic markers and low levels of mature hepatic markers and cytochrome P450 (CYP) activities) and cannot maintain a long-term differentiated phenotype [10-12]. This has led to the question of whether additional cues should be supplied in order to further improve the differentiation process.

Previous studies have shown that the in vivo environment can provide necessary signals to foster the maturation of stem cell-derived terminal cell types [13]. The in vivo cellular microenvironment contains not only soluble factors but also stromal cells and an insoluble extracellular matrix (ECM), a complex and dynamic network of macromolecules [14]. The hepatic differentiation efficiency of stem cells such as ESC has been shown to increase in the presence of stromal cells such as endothelial cells and fibroblasts $[15,16]$. By mixing hepatic progenitor cells with mesenchymal stem cells and/or endothelial cells, liver bud organoids could be produced with an expression profile more similar to human hepatic tissue [17].

In term of insoluble ECM, examples of macromolecules include collagen, fibronectin, and hyaluronic acid. Although the ECM was once considered an inert supportive scaffold, it is becoming evident that ECM plays an important role in organ development, function and wound repair [18-20]. The relative amounts and organization of different ECM components differ for each tissue which give rise to distinct physical and biochemical ECM properties [21]. Physical properties such as stiffness, porosity and topography have been shown to modulate stem cell differentiation [22-24]. From a biochemical point of view, the ECM components can regulate stem cell differentiation via direct binding with specific cell surface integrin (e.g., $\alpha 5 \beta 1$ ) or non-canonical growth factor presentation $[25,26]$. Therefore, natural or synthetic biomaterials can be employed to present physical and biochemical cues, which serve as additional stimuli to enhance hepatic differentiation of stem cells. While biomaterials such as collagen, laminin and decellularized ECM are traditionally applied as a 2D coating, the development of 3D biomaterial scaffolds has provided an alternative to influence cell fate via supplying ECM cues in 3D. Therefore, a systematic overview comparing and contrasting 2D and 3D biomaterial systems and their effects on stem cells is timely, providing a platform for future design of biomaterials to efficiently induce hepatic differentiation of stem cells for clinical and commercial applications.

In this review, we will discuss the application of various biomaterial systems in hepatic differentiation of stem cells in 2D and 3D culture (Figure 1), highlighting their role in promoting lineage specification and hepatic maturation. We start with introducing various stem cell sources, and then summarizing the examples of hepatic differentiation in 2D and 3D biomaterial systems. Finally, we will compare and contrast the effects of ECM on 2D and 3D culture. 


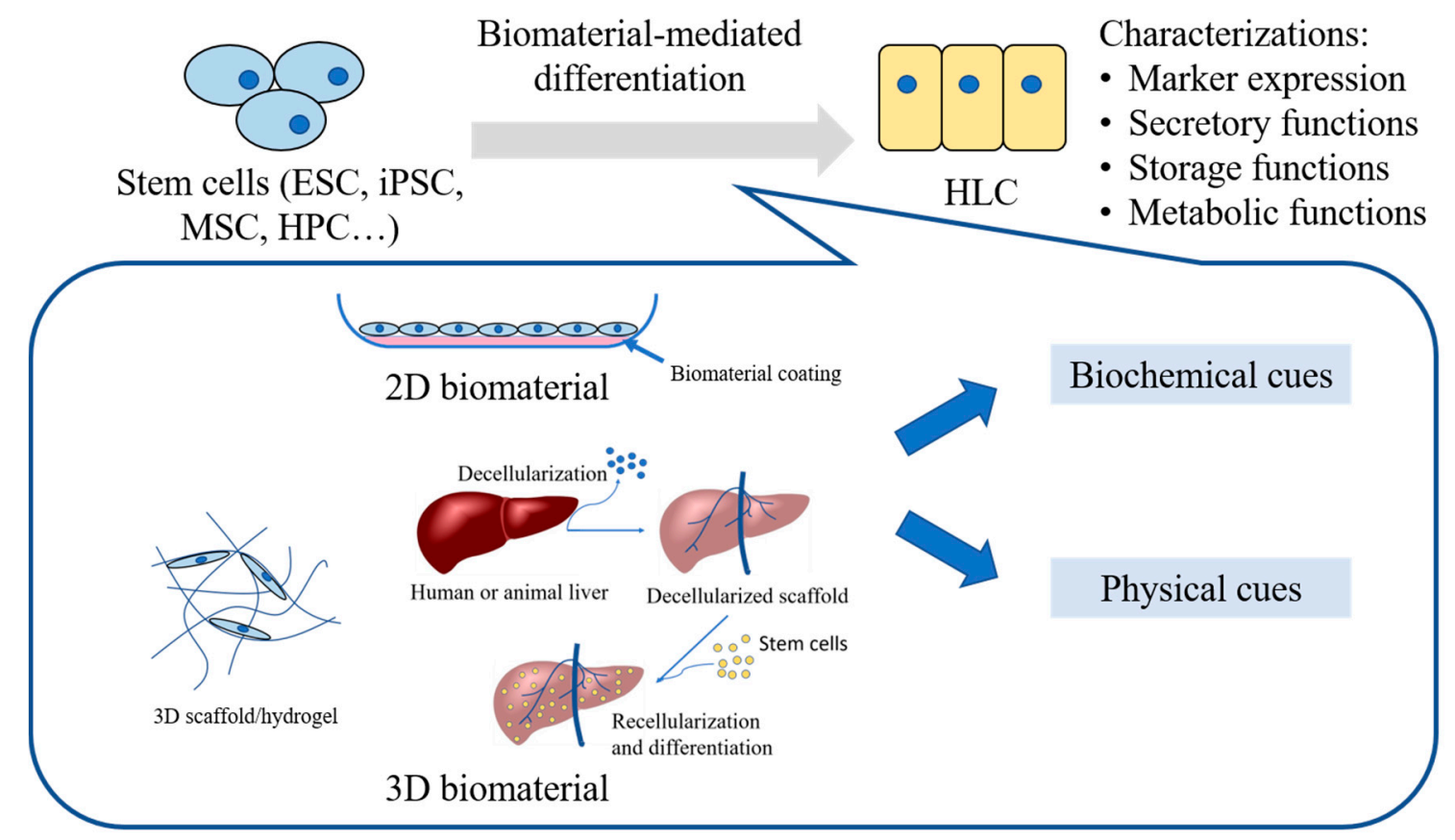

Figure 1. Schematic diagram of 2D and 3D biomaterial-mediated hepatic differentiation of stem cells.

\section{Sources of Stem Cells}

The inherent limitations of primary hepatocytes, including limited supply and rapid dedifferentiation during in vitro culture, have spurred efforts to explore alternative cell sources, including ESC, iPSC, MSC, HPC. ESC are derived from the inner cell mass of the blastocyst, are expandable, and can differentiate into three germ layer cell types [27]. The controversy over the ethical issues surrounding the procurement of ESC has been circumvented by the discovery of iPSC, which can be generated from terminally differentiated adult cells by forcibly expressing a selected group of transcription factors in the cells [28]. Both ESC and iPSC are pluripotent and can be directed to differentiate into HLC via a similar process paralleling the sequential hepatic development in vivo [29-34]. In one example, the differentiation process involves first inducing ESC and iPSC to differentiate into the definitive endoderm using growth factors or supplements such as Activin A and B27. Then hepatic endoderm is specified by addition of growth factors such as BMP-4 and FGF-2. This is followed by differentiation into immature and mature hepatocytes via adding HGF and oncostatin M, respectively [30]. Nevertheless, the potential of teratoma formation after implantation of both cell types poses a major risk of clinical use.

MSC, on the other hand, can be derived from different tissues, such as bone marrow, adipose tissue, placenta [35]. MSC are known to be multipotent and not pluripotent, so they do not contribute to teratoma formation [36]. In addition to differentiating into mesenchyme-related lineages, MSC can also transdifferentiate into HLC in the presence of a specialized array of growth factors [37]. A two-step protocol was reported in one example, in which MSC was first treated with HGF, bFGF, and nicotinamide. The supplementation of oncostatin $\mathrm{M}$, dexamethasone, and ITS was used to stimulate maturation thereafter [37].

Finally, HPC, also termed as oval cells, can be isolated and expanded from donated livers unsuitable for transplantation, which can then be induced to differentiate between hepatocyte and biliary lineages [38]. To induce differentiation to hepatocytes specifically, HPC can be cultured in the presence of HGF and FGF9 [39]. Meanwhile, human HPC cell lines, such as HepaRG, are also available for studying hepatic differentiation [40], and a similar stem cell population, termed resident liver stem cells and different from hepatic progenitor/stem cells by not expressing albumin, have also been reported [41]. One of the disadvantages, however, is the shortage of donor liver for HPC or liver 
stem cell isolation. Overall, a number of stem cell sources may be applied to produce HLC for clinical use for the treatment of liver diseases.

To determine differentiation efficiency, the expression of markers of various stages of differentiation can be evaluated, including Foxa2, Sox17 (definite endoderm), Hnf4 $\alpha$ (hepatic endoderm), AFP (immature hepatocyte) and/or albumin (mature hepatocyte) [30]. In addition, the secretion of albumin and urea can serve as functional outputs of HLC. HLC should also be able to storage glycogen and lipids. Finally, the metabolic functions of HLC can be assessed by measuring the expression and activity of enzymes such as CYP450 [31]. Next, we will discuss how various 2D and 3D biomaterial systems modulate hepatic differentiation of stem cells.

\section{Biomaterial Systems Employed in Hepatic Differentiation of Stem Cells}

Biomaterial was once defined as "a nonviable material used in a medical device, intended to interact with biological systems" as it was considered an inert supportive scaffold [42]. The definition was later revised as "material intended to interface with biological systems to evaluate, treat, augment or replace any tissue, organ or function of the body", reflecting an influencing the role of biomaterials on the human body in the context of tissue regeneration [43]. Biomaterials for modulating stem cell differentiation can be generally categorized into natural and synthetic polymers [44], and can be applied as $2 \mathrm{D}$ coatings or 3D scaffolds [45,46]. 3D scaffolds can be fabricated with conventional methods such as freeze-drying, particle leaching, and gas foam, whereas more advanced processing technologies such as $3 \mathrm{D}$ printing and microfluidic-based cell encapsulation have been recently developed to facilitate the control of scaffold properties (A detailed review of the fabrication technologies for tissue engineering was published elsewhere [47-49]).

Naturally-derived polymers, including protein and polysaccharides, have the potential advantage of biological recognition that renders them bioactive. However, natural materials often bring concerns such as weak mechanical strength and quick degradation rates [50]. Currently, Matrigel (or similar product such as Geltrex), which consists of a mixture of extracellular matrix proteins, proteoglycans, and growth factors derived from Engelbreth-Holm-Swarm sarcoma cells, has been extensively used as substrate in hepatic differentiation of stem cells [30,51-55]. However, one known disadvantage of Matrigel is that it suffers from potential batch-to-batch variability resulting in difficulty in generating reproducible cultures [56]. In contrast, synthetic polymers have received considerable attention due to their flexibility in composition and hence tunable properties [57]. In general, the chemical and physical properties of synthetic biomaterials can be controlled by altering the composition and fabrication condition. The following illustrates how biochemical and physical properties of biomaterials have been exploited in supporting hepatic differentiation of stem cells.

\subsection{Biomaterials Presenting Biochemical Cues}

\subsubsection{Natural and Composite Biomaterials}

Liver ECM is composed of collagenous proteins (different collagen types) as well as non-collagenous proteins and proteoglycans, such as fibronectin, perlecan, lumican and laminin [58]. The spatial expression and distribution of different ECM components has been shown to progressively change between fetal and adult liver [59], and between normal and regenerating liver [60], implicating the potential regulatory role of ECM in hepatic tissue development and regeneration. The principal ECM components in the liver are collagens, in particular collagen type I. Therefore, a number of studies have reported the use of collagen gels or scaffolds for hepatic differentiation of stem cells $[31,32,61]$. Culturing HLC derived from human iPSC on a 2D collagen vitrogel membrane was shown to promote hepatic differentiation and maturation by reducing the expression of immature hepatic markers (e.g., alpha fetoprotein (AFP)) while increasing the expression of mature hepatocyte markers (e.g., albumin (ALB)) compared with Matrigel coating [61]. Additionally, 3D encapsulation of HLC clumps derived from iPSC in collagen hydrogel could also improve the maturation of HLC when 
compared with 2D culture using tissue culture dish coated with gelatin [31]. Similarly, encapsulation of embryoid bodies (EB) constructed from ESC in a collagen hydrogel could foster hepatic differentiation by enhancing the expression of hepatic markers such as ALB when compared with seeding the EB on collagen-coated dishes [32].

Apart from collagen, other ECM components, including vitronectin and laminin, were also shown to have a beneficial effect on the hepatic differentiation of ESC when used as 2D coating. The vitronectin-coated substrates supported hepatic differentiation at a similar level to Matrigel [33], while certain laminin subtypes outperformed Matrigel as evidenced by a higher expression of CYP450 activity and a shift towards fresh hepatocytes in principal component analysis of 1000 genes [34]. These ECM components could provide a chemically-defined, xeno-free alternative to Matrigel and facilitate good manufacturing practice (GMP) manufacturing of HLC.

Polysaccharides are another class of natural biomaterial widely used in biomedical research. Alginate encapsulation of MSC improved hepatic differentiation compared with 2D culture by producing HLC with higher albumin and urea secretions [62]. ESC encapsulated in alginate were also shown to be able to differentiate into HLC [63]. Although alginate is considered bioinert and does not provide cell adhesion motifs, it can be modified with peptides, such as Arg-Gly-Asp (RGD), to increase bioactivity [64].

The other natural ECM biomaterial that was investigated is decellularized liver scaffolds [65]. Whole organ decellularization can be achieved by perfusion of the organs with various detergents, and the resulting scaffold maintains the native ECM microarchitecture and retains numerous bioactive signals such as growth factors that are difficult to replicate artificially. Consequently, decellularized scaffolds are a promising biomaterial for tissue engineering [66]. Two independent studies have compared the hepatic differentiation of MSC infused within the 3D decellularized liver scaffold (recellularization) and in 2D culture $[67,68]$. Both found that greater yields of mature, differentiated HLC were obtained in the scaffold culture, suggesting the possibility to repopulate the decellularized scaffold with stem cells for differentiation and direct implantation. Similar results were demonstrated for differentiation of human liver stem cells into HLC [69]. A direct comparison between decellularized liver scaffold and collagen type I scaffold (poly-L-lactic acid-collagen) demonstrated that the former induced superior hepatocyte maturation of HLC derived from iPSC compared with the latter [70], and that the effect is likely mediated by the complex composition of decellularized ECM compared with the single ECM component in the collagen scaffold. Furthermore, when used as a 2D coating, decellularized ECM was shown to outperform collagen, fibronectin and Matrigel in enhancing the hepatic differentiation of MSC [71,72]. Despite the promise it shows, batch-to-batch variability of scaffold properties could limit the widespread use of decellularized scaffolds for directing stem cell differentiation [73].

Composite biomaterials with two or more natural polymers have also been reported. The conjugation of heparin, which has a high affinity for a variety of growth factors, to a collagen scaffold led to enhanced hepatic differentiation of MSC as indicated by higher percentage of cells expressing cytokeratin 19 and ALB [74]. It is likely that heparin immobilizes growth factors such as hepatocyte growth factor, a known growth factor for hepatocyte differentiation, to present the signals locally. In another study, three different composite scaffolds were constructed including dextran-gelatin, chitosan-hyaluronic acid, and gelatin-vinyl acetate [75]. Based on the assessment of hepatic marker expression and metabolic functions, all 3D scaffolds outperformed 2D culture and gelatin-vinyl acetate was found to be the most preferable scaffold to support differentiation of MSC into HLC. The authors attributed their findings to the fact that collagen, where gelatin is derived from, is a major component of liver ECM. Finally, HepaRG cells, which is a human HPC cell line and shares features with oval cells such as being bipotent, were cultured on two composite biomaterials, namely nanofibrillar cellulose and hyaluronan-gelatin hydrogels [76]. Both hydrogels induced the formation of HepaRG spheroids and stimulated the hepatic differentiation via increasing hepatic marker expression and metabolic functions. Since the difference of the differentiation efficiencies was small between the two biomaterials, 
the induction effects are likely due to the restoration of cell-cell interaction in spheroid culture rather than specific ECM cues.

\subsubsection{Synthetic Biomaterials}

The advantages of synthetic biomaterials include tunable and reproducible properties, such as stiffness, degradation rate, swelling rate. Synthetic biomaterials such as poly(lactic-co-glycolic acid) (PLGA) and polyethylene glycol (PEG) are often used to fabricate 3D scaffolds [77]. In order to present biochemical cues close to those in the in vivo environment, composite biomaterials consisting of both synthetic and natural polymers with physical or chemical interactions have been developed. For instance, a collagen-coated PLGA 3D scaffold was used to support hepatic differentiation of MSC [78], with the expression of hepatic markers appearing earlier and the metabolic functions higher compared with 2D culture. In another report, a PEG-based scaffold constructed with an inverted colloidal crystal approach and containing uniform pores $(100 \mu \mathrm{m}$ in diameter $)$ was coated with fibronectin and/or collagen [79]. Results showed that the presence of both biochemical cues produced superior induction effects on the hepatic differentiation of MSC, when compared with the scaffold coated with collagen only or the 2D control.

\subsection{Biomaterial Systems Presenting Physical Cues}

When a specific ECM component (e.g., fibronectin) binds with integrins that recognize the motifs on the ECM (e.g., $\alpha 5 \beta 1$ ), focal adhesion kinase is activated to mediate downstream signaling to elicit an ECM-specific response on stem cell differentiation [80,81]. Meanwhile, integrins and the focal adhesion complex proteins are also known as mechanosensors and mechanotransducers that sense and transduce physical/mechanical signals into biochemical signals. Focal adhesions are protein complexes that form upon the binding of integrin to ECM, and link the ECM to the intracellular cytoskeleton. The subsequent interaction between signaling proteins will activate downstream effectors, such as Rho, to influence cell behavior [82]. Examples of physical signals are stiffness and topography. Using a 2D micropatterned heparin hydrogel, Y. Huang et al. showed that soft hydrogels ( 400 $\mathrm{Pa})$ promoted MSC differentiation into HLC and hepatic maturation compared with stiffer hydrogels (up to $\sim 43 \mathrm{kPa}$ ) [83]. Similarly, collagen-coated polyacrylamide hydrogels with stiffness of 20-140 kPa were shown to enhance albumin secretion as well as the metabolic activities of HLC derived from ESC compared with tissue culture dish ( $\sim 3 \mathrm{GPa})$ [84]. Moreover, culturing resident liver stem cells on soft polyacrylamide hydrogels (400 Pa) enhanced the differentiation of resident liver stem cells to hepatocytes compared to stiffer hydrogels $(80 \mathrm{kPa})$ [85]. The above findings are consistent with the observation that primary hepatocytes cultured on substrates with stiffness similar to that of the liver $(\sim 10 \mathrm{kPa})$ maintain their differentiated phenotype for longer durations [86]. For 3D culture, encapsulating HepRG cells in a PEG-hyaluronic acid hydrogel conjugated with hydrolytically degradable peptide was used to determine the optimal stiffness environment for differentiation [87]. The elastic modulus of each hydrogel was modulated dynamically due to the combined effects of hydrogel degradation and extracellular matrix production by the encapsulated cells. At a stiffness ( 2.8 to $6.17 \mathrm{kPa})$ close to that of the native liver, hepatic differentiation was more mature in terms of hepatic gene expression, albumin secretion, CYP3A4 activity, and drug metabolism.

Other physical properties which highly influence 3D culture efficiency are porosity and pore size. A polymer scaffold with high porosity, such as an electrospun fibrous scaffold, facilitates metabolic functions of hepatocytes and allows exchange of nutrients and wastes [88]. A porous poly(L-lactic acid)-co-poly ( $\varepsilon$-caprolactone) (PLACL)/collagen scaffold with $89 \%$ porosity was found to enhance MSC differentiation into HLC compared with PLACL and collagen scaffolds [89]. Scaffolds with large surface to volume ratios have also been shown to promote hepatocyte attachment [90]. In terms of pore size, collagen scaffolds fabricated with various pore sizes $(10,18,82 \mu \mathrm{m})$ were shown to influence the secretory function of hepatocytes and their cell-cell interaction [91]. Specifically, a scaffold with $18 \mu \mathrm{m}$ pores was found to reduce hepatocyte secretory function as well as expression of 
cell-cell adhesion proteins compared with scaffolds with $10 \mu \mathrm{m}$ or $82 \mu \mathrm{m}$ pores. This was attributed to the significantly higher degree of cell spreading within the $18 \mu \mathrm{m}$ scaffold which repressed hepatic differentiation.

In order to present topographical cues, nanoscale fibers can be fabricated to mimic the native ECM architecture [92]. Signal transduction can be triggered when stem cells are exposed to cues via integrin binding/focal adhesion formation. Cells exposed to topographical signals have been shown to exhibit upregulation of focal adhesion kinase expression as well as phosphorylation. This is expected to trigger downstream signaling as described in the previous paragraph [93]. In one example, topographical cues presented by electrospun nanofibers (chitosan/polycaprolactone) were shown to influence stem cell differentiation [94]. When ESC were cultured on the fibers of $400 \mathrm{~nm}$ and $1.1 \mu \mathrm{m}$ in diameter, ectodermal commitment was stimulated whereas fibers of $200 \mathrm{~nm}$ in diameter promoted hepatic differentiation. A nanopatterned surface with $120 \mathrm{~nm}$ of pit spacing was fabricated by electron beam lithography and was shown to promote hepatic differentiation of HepaRG compared with tissue culture dish [95]. These results strongly suggest that tailored ECM-like substrates are capable of influencing the hepatic differentiation of stem cells.

\section{Comparison between 2D and 3D Biomaterial Systems}

It has been increasingly recognized that $3 \mathrm{D}$ cell culture provides a more realistic biochemical and physical microenvironment than 2D cell culture [96,97]. In directing stem cell differentiation, 3D cultures such as generating embryoid bodies or spheroids, which mimic the early stages of embryogenesis and morphogenesis, have been shown to improve differentiation efficiency when compared with 2D culture [98]. In addition, embedding stem cells in 3D scaffold was also seen to enhance the efficiency of stem cell differentiation [99]. Interestingly, the 2D and 3D configurations of stem cells could lead to differential responses when cells are exposed to the same ECM cue. Here we summarize the studies of hepatic differentiation of stem cells in 2D and 3D biomaterial systems with the aim of elucidating the biomaterial effect in different cell culture configurations (Table 1). Although there is a lack of studies comparing 2D and 3D biomaterial systems directly, we can still note the following observations. 1. Decellularized ECM and collagen, the major ECM component in liver, can support hepatic differentiation in both 2D and 3D configurations. In general, encapsulating stem cells in a collagen scaffold produced more mature HLC than inducing stem cell differentiation on a collagen/gelatin-coated substrate [31,32]. 2. Soft biomaterial $(<10 \mathrm{kPa})$ enhanced hepatic differentiation in both 2D and 3D configurations $[84,87]$. 3. Whereas biomaterial is always introduced at the beginning in 2D differentiation, the timing of embedding stem cells in biomaterial for 3D differentiation could vary. Biomaterials could either be supplied to guide lineage specification at the initial stage [78], or be supplemented after HLC were generated to boost their maturation [31]. This suggests the ECM cues may have a temporal effect which has not yet been revealed. A systematic investigation should be conducted to study the temporal effect of ECM cues by introducing a biomaterial scaffold to stem cell differentiation at various time points. Meanwhile, the mechanistic knowledge of how 2D and 3D biomaterial systems may differentially regulate stem cell differentiation is limited. One study reported that integrin expression was altered when ECM cues were presented in 2D and 3D [100]. This is likely to affect the expression of downstream signaling molecules, such as focal adhesion kinase (FAK) and extracellular signal-regulated kinase (ERK) [80], which warrants further investigation. 
Table 1. Summary of 2D and 3D biomaterial systems applied in hepatic differentiation of stem cells.

\begin{tabular}{|c|c|c|c|}
\hline Biomaterial Systems & Stem Cell Sources & $\begin{array}{c}\text { Differentiation Efficiency } \\
\text { (\% of Albumin-Positive Cells) }\end{array}$ & Ref. \\
\hline \multirow{2}{*}{\multicolumn{4}{|c|}{$\begin{array}{l}\text { Biochemical cues } \\
2 \mathrm{D}\end{array}$}} \\
\hline & & & \\
\hline Collagen & iPSC & $54.3 \%$ (day 25 ) & [61] \\
\hline Decellularized liver ECM & MSC & $26.7 \%$ (day 21 ) & [71] \\
\hline Laminin & ESC & $91.3 \%$ (day 18 ) & [34] \\
\hline Matrigel & ESC, iPSC, MSC & $\begin{array}{c}80.9 \% \text { (day 20) [30]; } 90 \% \text { (day 17) [52]; } \\
91 \% \text { (day 14) [53] }\end{array}$ & {$[30,51-55]$} \\
\hline $\begin{array}{l}\text { Vitronectin } \\
\text { 3D }\end{array}$ & ESC, iPSC & Not provided & [33] \\
\hline Alginate & ESC, MSC & $87 \%$ (day 20) [63] & {$[62,63]$} \\
\hline Collagen & ESC & Not provided & {$[31,32]$} \\
\hline Cellulose, hyaluronan-gelatin & HepaRG & Not provided & [76] \\
\hline Decellularized liver ECM & ESC, iPSC, MSC & Not provided & {$[67,68,70]$} \\
\hline $\begin{array}{l}\text { Dextran-gelatin, } \\
\text { chitosan-hyaluronic acid, } \\
\text { gelatin-vinyl acetate }\end{array}$ & MSC & $\begin{array}{l}\text { Dextran-gelatin: } 57.2 \% \text { (day 28); } \\
\text { chitosan-hyaluronic acid: } 62.8 \% \text { (day } 28) \\
\text { gelatin-vinyl acetate: } 68.1 \% \text { (day } 28 \text { ) }\end{array}$ & [75] \\
\hline Heparin-collagen & MSC & Not provided & [74] \\
\hline PEG-collagen/fibronectin & MSC & Not provided & [79] \\
\hline PLGA-collagen & MSC & Not provided & [78] \\
\hline \multicolumn{4}{|l|}{$\begin{array}{l}\text { Physical cues } \\
\text { (stiffness/topography/porosity } \\
\text { and pore size) } \\
\text { 2D }\end{array}$} \\
\hline Heparin (stiffness) & MSC & $\sim 60 \%$ (day 21 ) & [83] \\
\hline Polyacrylamide (stiffness) & $\begin{array}{l}\text { ESC, iPSC, Resident liver } \\
\text { stem cells }\end{array}$ & Not provided & {$[84,85]$} \\
\hline 3D & & & \\
\hline Chitosan (topography) & ESC & Not provided & [94] \\
\hline $\begin{array}{l}\text { PEG/hyaluronic acid (stiffness) } \\
\text { Poly(L-lactic acid)-co-poly }\end{array}$ & HepaRG & Not provided & [87] \\
\hline $\begin{array}{l}\text { ( } \varepsilon \text {-caprolactone) (PLACL)/collagen } \\
\text { (porosity) }\end{array}$ & MSC & Not provided & [89] \\
\hline
\end{tabular}

\section{Conclusions and Future Perspectives}

The capability of stem cells to differentiate into HLC is well documented, but producing HLC with a mature hepatocyte phenotype remains a challenge. Previously, functional maturation of HLC was observed by comparing the phenotype of HLC before and after implantation into an animal model [17]. This implied that maturing stimuli are present in the in vivo cellular environment. Notwithstanding, traditional approaches to induce stem cell differentiation rely primarily on soluble chemical signals only. In addition to soluble factors, the cellular environment in the liver also comprises supporting cells and ECM in direct contact with hepatocytes. To recapitulate the ECM environment, both natural and synthetic materials can be used to provide biochemical and physical cues. While Matrigel and decellularized ECM can recapitulate the complex compositions of native ECM, the increasing use of chemically-defined biomaterials should facilitate the design of biomaterials to promote hepatic differentiation of stem cells as well as GMP production of HLC for clinical applications. For example, an optimized scaffold can be fabricated based on a combination of chemically-defined biomaterials, such as laminin and vitronectin, which have been shown to enhance hepatic differentiation and maturation in previous studies [33,34]. As mentioned in the beginning of the article, the crosstalk between different hepatic cell types is important in promoting hepatic differentiation. Given that different hepatic cell types are located at specialized locations in the liver sinusoid and the distribution of liver ECM is heterogeneous [101], the biomaterial scaffold could also be optimized by providing the spatial organization of various cell types as well as ECM components to allow the fabrication of a fully functional artificial liver.

In this review article, we have provided an overview of various 2D and 3D biomaterial systems applied in hepatic differentiation of stem cells. Although the similarities and differences between the effect of 2D and 3D biomaterial systems were not covered in great detail due to a lack of relevant studies, we have shown that the differences between 2D and 3D biomaterial systems could potentially impact the differentiation efficiency. Therefore, efforts should be devoted to further elucidating 
how biomaterial configurations influence hepatic differentiation of stem cells and optimizing the differentiation protocol in terms of biomaterial composition and configuration. The biomaterial effect on hepatic differentiation of stem cells mediated by overexpression of microRNAs (miRNAs) such as miRNA-122 and miRNA-194 as well as overexpression of transcription factors such as Foxa2/Hnf4a should also be investigated [102-104]. We envision that the combined and optimized use of soluble factors and biomaterial scaffolds should pave the way for more efficient derivation of useful HLC in the future.

Author Contributions: All authors contributed to the conceptualization, writing, review and editing of the manuscript. All authors have read and agreed to the published version of the manuscript.

Funding: This research was funded by the National Key R\&D Program of China (2019YFA0111300, 2018YFA0903400), General Research Fund- Early Career Scheme (24204819), and Chinese University of Hong Kong Direct Grant (2018.018) and Start up fund.

Conflicts of Interest: The authors declare no conflict of interest.

\section{References}

1. Alqahtani, S.A. Update in liver transplantation. Curr. Opin. Gastroenterol. 2012, 28, 230-238. [CrossRef] [PubMed]

2. Asrani, S.K.; Devarbhavi, H.; Eaton, J.; Kamath, P.S. Burden of liver diseases in the world. J. Hepatol. 2019, 70, 151-171. [CrossRef] [PubMed]

3. Bodzin, A.S.; Baker, T.B. Liver Transplantation Today: Where We Are Now and Where We Are Going. Liver Transplant. 2018, 24, 1470-1475. [CrossRef]

4. Muraca, M.; Gerunda, G.E.; Neri, D.; Vilei, M.T.; Granato, A.; Feltracco, P.; Giron, G.; Burlina, A.B. Hepatocyte transplantation as a treatment for glycogen storage disease type IA. J. Hepatol. 2002, 36, 41. [CrossRef]

5. Langer, R.; Vacanti, J. Advances in tissue engineering. J. Pediatr. Surg. 2015, 51, 8-12. [CrossRef]

6. Demetriou, A.A.; Brown, R.S., Jr.; Busuttil, R.W.; Fair, J.; McGuire, B.M.; Rosenthal, P.; Am Esch, J.S. Prospective, Randomized, Multicenter, Controlled Trial of a Bioartificial Liver in Treating Acute Liver Failure. Ann. Surg. 2004, 239, 660-667. [CrossRef]

7. Ang, L.T.; Tan, A.K.Y.; Autio, M.I.; Goh, S.H.; Choo, S.H.; Lee, K.L.; Tan, J.; Pan, B.; Lee, J.J.H.; Lum, J.J.; et al. A Roadmap for Human Liver Differentiation from Pluripotent Stem Cells. Cell Rep. 2018, 22, 2190-2205. [CrossRef]

8. Cotovio, J.P.; Fernandes, T.G. Production of Human Pluripotent Stem Cell-Derived Hepatic Cell Lineages and Liver Organoids: Current Status and Potential Applications. Bioengineering 2020, 7, 36. [CrossRef]

9. McKee, C.; Chaudhry, G.R. Advances and challenges in stem cell culture. Colloids Surfaces B Biointerfaces 2017, 159, 62-77. [CrossRef]

10. Baxter, M.; Withey, S.; Harrison, S.; Segeritz, C.-P.; Zhang, F.; Atkinson-Dell, R.; Rowe, C.; Gerrard, D.; Sison-Young, R.; Jenkins, R.; et al. Phenotypic and functional analyses show stem cell-derived hepatocyte-like cells better mimic fetal rather than adult hepatocytes. J. Hepatol. 2014, 62, 581-589. [CrossRef]

11. Yu, Y.; Liu, H.; Ikeda, Y.; Amiot, B.P.; Rinaldo, P.; Duncan, S.A.; Nyberg, S.L. Hepatocyte-like cells differentiated from human induced pluripotent stem cells: Relevance to cellular therapies. Stem Cell Res. 2012, 9, 196-207. [CrossRef] [PubMed]

12. Lee, J.-H.; Park, H.-J.; Jang, I.; Kim, H.-E.; Lee, D.-H.; Park, J.-K.; Lee, S.-K.; Yoon, H.H. In Vitro Differentiation of Human Liver-derived Stem Cells with Mesenchymal Characteristics into Immature Hepatocyte-like Cells. Transplant. Proc. 2014, 46, 1633-1637. [CrossRef] [PubMed]

13. Kadota, S.; Pabon, L.; Reinecke, H.; Murry, C.E. In Vivo Maturation of Human Induced Pluripotent Stem Cell-Derived Cardiomyocytes in Neonatal and Adult Rat Hearts. Stem Cell Rep. 2017, 8, 278-289. [CrossRef] [PubMed]

14. Clause, K.C.; Barker, T.H. Extracellular matrix signaling in morphogenesis and repair. Curr. Opin. Biotechnol. 2013, 24, 830-833. [CrossRef]

15. Yu, Y.-D.; Kim, K.-H.; Lee, S.-G.; Choi, S.-Y.; Kim, Y.-C.; Byun, K.-S.; Cha, I.-H.; Park, K.-Y.; Cho, C.-H.; Choi, D.-H. Hepatic Differentiation from Human Embryonic Stem Cells Using Stromal Cells. J. Surg. Res. 2011, 170, e253-e261. [CrossRef] 
16. Pettinato, G.; Lehoux, S.; Ramanathan, R.; Salem, M.M.; He, L.-X.; Muse, O.; Flaumenhaft, R.; Thompson, M.T.; Rouse, E.A.; Cummings, R.D.; et al. Generation of fully functional hepatocyte-like organoids from human induced pluripotent stem cells mixed with Endothelial Cells. Sci. Rep. 2019, 9, 8920. [CrossRef]

17. Takebe, T.; Sekine, K.; Enomura, M.; Koike, H.; Kimura, M.; Ogaeri, T.; Zhang, R.; Ueno, Y.; Zheng, Y.-W.; Koike, N.; et al. Vascularized and functional human liver from an iPSC-derived organ bud transplant. Nature 2013, 499, 481-484. [CrossRef]

18. Aufschnaiter, R.; Zamir, E.A.; Little, C.D.; Özbek, S.; Münder, S.; David, C.N.; Li, L.; Sarras, M.P.; Zhang, X. In vivo imaging of basement membrane movement: ECM patterning shapes Hydra polyps. J. Cell Sci. 2011, 124, 4027-4038. [CrossRef] [PubMed]

19. Hassan, A.; Sapir, L.; Nitsan, I.; Ben-El, R.T.G.; Halachmi, N.; Salzberg, A.; Tzlil, S. A Change in ECM Composition Affects Sensory Organ Mechanics and Function. Cell Rep. 2019, 27, 2272-2280.e4. [CrossRef]

20. Sato, E.; Zhang, L.-J.; Dorschner, R.A.; Adase, C.A.; Choudhury, B.P.; Gallo, R.L. Activation of Parathyroid Hormone 2 Receptor Induces Decorin Expression and Promotes Wound Repair. J. Investig. Dermatol. 2017, 137, 1774-1783. [CrossRef]

21. Mouw, J.K.; Ou, G.; Weaver, V.M. Extracellular Matrix Assembly: A Multiscale Deconstruction. Nat. Rev. Mol. Cell Biol. 2014, 15, 771-785. [CrossRef] [PubMed]

22. Engler, A.J.; Sen, S.; Sweeney, H.L.; E Discher, D. Matrix Elasticity Directs Stem Cell Lineage Specification. Cell 2006, 126, 677-689. [CrossRef] [PubMed]

23. Lee, B.L.-P.; Tang, Z.; Wang, A.; Huang, F.; Yan, Z.; Wang, N.; Chu, J.S.; Dixit, N.; Yang, L.; Li, S. Synovial stem cells and their responses to the porosity of microfibrous scaffold. Acta Biomater. 2013, 9, 7264-7275. [CrossRef] [PubMed]

24. Yim, E.K.; Pang, S.W.; Leong, K.W. Synthetic nanostructures inducing differentiation of human mesenchymal stem cells into neuronal lineage. Exp. Cell Res. 2007, 313, 1820-1829. [CrossRef]

25. Du, J.; Chen, X.; Liang, X.; Zhang, G.; Xu, J.; He, L.; Zhan, Q.; Feng, X.-Q.; Chien, S.; Yang, C. Integrin activation and internalization on soft ECM as a mechanism of induction of stem cell differentiation by ECM elasticity. Proc. Natl. Acad. Sci. USA 2011, 108, 9466-9471. [CrossRef]

26. Dombrowski, C.; Song, S.J.; Chuan, P.; Lim, X.; Susanto, E.; Sawyer, A.A.; Woodruff, M.A.; Hutmacher, D.W.; Nurcombe, V.; Cool, S.M. Heparan Sulfate Mediates the Proliferation and Differentiation of Rat Mesenchymal Stem Cells. Stem Cells Dev. 2009, 18, 661-670. [CrossRef]

27. Chen, A.E.; Egli, D.; Niakan, K.; Deng, J.; Akutsu, H.; Yamaki, M.; Cowan, C.; Fitz-Gerald, C.; Zhang, K.; Melton, D.A.; et al. Optimal Timing of Inner Cell Mass Isolation Increases the Efficiency of Human Embryonic Stem Cell Derivation and Allows Generation of Sibling Cell Lines. Cell Stem Cell 2009, 4, 103-106. [CrossRef]

28. Takahashi, K.; Tanabe, K.; Ohnuki, M.; Narita, M.; Ichisaka, T.; Tomoda, K.; Yamanaka, S. Induction of Pluripotent Stem Cells from Adult Human Fibroblasts by Defined Factors. Cell 2007, 131, 861-872. [CrossRef]

29. Carpentier, A.; Nimgaonkar, I.; Chu, V.; Xia, Y.; Hu, Z.; Liang, T.J. Hepatic differentiation of human pluripotent stem cells in miniaturized format suitable for high-throughput screen. Stem Cell Res. 2016, 16, 640-650. [CrossRef]

30. Si-Tayeb, K.; Noto, F.K.; Nagaoka, M.; Li, J.; Battle, M.A.; Duris, C.; North, P.E.; Dalton, S.; Duncan, S.A. Highly efficient generation of human hepatocyte-like cells from induced pluripotent stem cells. Hepatology 2010, 51, 297-305. [CrossRef]

31. Iii, R.L.G.; Hannan, N.R.F.; Bort, R.; Hanley, N.; Drake, R.A.L.; Cameron, G.W.W.; Wynn, T.A.; Vallier, L. Maturation of Induced Pluripotent Stem Cell Derived Hepatocytes by 3D-Culture. PLoS ONE 2014, 9, e86372. [CrossRef]

32. Imamura, T.; Cui, L.; Teng, R.; Johkura, K.; Okouchi, Y.; Asanuma, K.; Ogiwara, N.; Sasaki, K. Embryonic Stem Cell-Derived Embryoid Bodies in Three-Dimensional Culture System form Hepatocyte-Like Cells in Vitro and in Vivo. Tissue Eng. 2004, 10, 1716-1724. [CrossRef] [PubMed]

33. Nagaoka, M.; Kobayashi, M.; Kawai, C.; Mallanna, S.K.; Duncan, S.A. Design of a Vitronectin-Based Recombinant Protein as a Defined Substrate for Differentiation of Human Pluripotent Stem Cells into Hepatocyte-Like Cells. PLoS ONE 2015, 10, e0136350. [CrossRef] [PubMed]

34. Cameron, K.; Tan, R.; Schmidt-Heck, W.; Campos, G.; Lyall, M.J.; Wang, Y.; Lucendo-Villarin, B.; Szkolnicka, D.; Bates, N.; Kimber, S.J.; et al. Recombinant Laminins Drive the Differentiation and Self-Organization of Hesc-Derived Hepatocytes. Stem Cell Rep. 2015, 5, 1250-1262. [CrossRef] [PubMed] 
35. Tsuchiya, A.; Takeuchi, S.; Watanabe, T.; Yoshida, T.; Nojiri, S.; Ogawa, M.; Terai, S. Mesenchymal stem cell therapies for liver cirrhosis: MSCs as "conducting cells" for improvement of liver fibrosis and regeneration. Inflamm. Regen. 2019, 39, 1-6. [CrossRef] [PubMed]

36. Hass, R.; Kasper, C.; Böhm, S.; Jacobs, R. Different populations and sources of human mesenchymal stem cells (MSC): A comparison of adult and neonatal tissue-derived MSC. Cell Commun. Signal. 2011, 9, 12. [CrossRef]

37. Lee, K.-D.; Kuo, T.K.-C.; Whang-Peng, J.; Chung, Y.-F.; Lin, C.-T.; Chou, S.-H.; Chen, J.-R.; Chen, Y.-P.; Lee, O.K.-S. In vitro hepatic differentiation of human mesenchymal stem cells. Hepatol. 2004, 40, 1275-1284. [CrossRef]

38. Darwiche, H.; Petersen, B.E. Biology of the Adult Hepatic Progenitor Cell. Prog. Mol. Biol. Transl. Sci. 2010, 97, 229-249. [CrossRef]

39. Liu, W.; Wang, Y.; Sun, Y.; Wu, Y.; Ma, Q.; Shi, Y.; He, R.; Zhang, T.; Ma, Y.; Zuo, W.; et al. Clonal expansion of hepatic progenitor cells and differentiation into hepatocyte-like cells. Dev. Growth Differ. 2019, 61, $203-211$. [CrossRef]

40. Jang, M.; Kleber, A.; Ruckelshausen, T.; Betzholz, R.; Manz, A. Differentiation of the human liver progenitor cell line (HepaRG) on a microfluidic-based biochip. J. Tissue Eng. Regen. Med. 2019, 13, 482-494. [CrossRef]

41. Conigliaro, A.; Colletti, M.; Cicchini, C.; Guerra, M.T.; Manfredini, R.; Zini, R.; Bordoni, V.; Siepi, F.; Leopizzi, M.; Tripodi, M.; et al. Isolation and characterization of a murine resident liver stem cell. Cell Death Differ. 2007, 15, 123-133. [CrossRef] [PubMed]

42. Ai, H.; Anderson, J.; Anseth, K.; Antoniac, I.; Barbosa, M.; Basu, B.; Best, S.; Bettini, R.; Bezuidenhout, D.; Bizios, R.; et al. Attendees at Chengdu Definitions in Biomaterials Conference 2019. In Proceedings of the Definitions of Biomaterials for the Twenty-First Century; Elsevier: Amsterdam, The Netherlands, 2019.

43. Reis, R.L. 2nd Consensus conference on definitions on biomaterials science. J. Tissue Eng. Regen. Med. 2020, 14, 561-562. [CrossRef] [PubMed]

44. Kohane, D.S.; Langer, R. Polymeric Biomaterials in Tissue Engineering. Pediatr. Res. 2008, 63, $487-491$. [CrossRef] [PubMed]

45. Lee, J.; Abdeen, A.A.; Zhang, D.; Kilian, K.A. Directing stem cell fate on hydrogel substrates by controlling cell geometry, matrix mechanics and adhesion ligand composition. Biomaterials 2013, 34, 8140-8148. [CrossRef]

46. Cunha, C.; Panseri, S.; Villa, O.; Silva, D.; Gelain, F. 3D culture of adult mouse neural stem cells within functionalized self-assembling peptide scaffolds. Int. J. Nanomed. 2011, 6, 943-955. [CrossRef]

47. Jeong, H.-J.; Nam, H.; Jang, J.; Lee, S.-J. 3D Bioprinting Strategies for the Regeneration of Functional Tubular Tissues and Organs. Bioengineering 2020, 7, 32. [CrossRef]

48. Mirdamadi, M.E.S.; Kalhori, D.; Zakeri, N.; Azarpira, N.; Solati-Hashjin, M. Liver Tissue Engineering as an Emerging Alternative for Liver Disease Treatment. Tissue Eng. Part B Rev. 2020, 26, 145-163. [CrossRef]

49. Morais, A.D.S.; Vieira, S.; Zhao, X.; Mao, Z.; Gao, C.; Oliveira, J.M.; Reis, R.L. Advanced Biomaterials and Processing Methods for Liver Regeneration: State-of-the-Art and Future Trends. Adv. Heal. Mater. 2020, 9, e1901435. [CrossRef]

50. Song, R.; Murphy, M.; Li, C.; Ting, K.; Soo, C.; Zheng, Z. Current development of biodegradable polymeric materials for biomedical applications. Drug Des. Dev. Ther. 2018, 12, 3117-3145. [CrossRef]

51. Lucendo-Villarin, B.; Rashidi, H.; Cameron, K.; Hay, D.C. Pluripotent stem cell derived hepatocytes: Using materials to define cellular differentiation and tissue engineering. J. Mater. Chem. B 2016, 4, 3433-3442. [CrossRef]

52. Hay, D.C.; Fletcher, J.; Payne, C.; Terrace, J.D.; Gallagher, R.C.J.; Snoeys, J.; Black, J.R.; Wojtacha, D.; Samuel, K.; Hannoun, Z.; et al. Highly efficient differentiation of hESCs to functional hepatic endoderm requires ActivinA and Wnt3a signaling. Proc. Natl. Acad. Sci. USA 2008, 105, 12301-12306. [CrossRef] [PubMed]

53. Sullivan, G.; Hay, D.C.; Park, I.-H.; Fletcher, J.; Hannoun, Z.; Payne, C.M.; Dalgetty, N.; Black, J.R.; Ross, J.A.; Samuel, K.; et al. Generation of functional human hepatic endoderm from human induced pluripotent stem cells. Hepatology 2010, 51, 329-335. [CrossRef] [PubMed]

54. Touboul, T.; Vallier, L.; Weber, A. Robust Differentiation of Fetal Hepatocytes from Human Embryonic Stem Cells and Ips. Med. Sci. (Paris) 2010, 26, 1061-1066. [CrossRef]

55. Schwartz, R.E.; Reyes, M.; Koodie, L.; Jiang, Y.; Blackstad, M.; Lund, T.; Lenvik, T.; Johnson, S.; Hu, W.S.; Verfaillie, C.M. Multipotent Adult Progenitor Cells from Bone Marrow Differentiate into Functional Hepatocyte-Like Cells. J. Clin. Investig. 2002, 109, 1291-1302. [CrossRef] 
56. Serban, M.A.; Prestwich, G.D. Modular extracellular matrices: Solutions for the puzzle. Methods 2008, 45, 93-98. [CrossRef]

57. Zhu, J.; E Marchant, R. Design properties of hydrogel tissue-engineering scaffolds. Expert Rev. Med. Devices 2011, 8, 607-626. [CrossRef]

58. Goddard, E.; Hill, R.C.; Barrett, A.; Betts, C.; Guo, Q.; Maller, O.; Borges, V.F.; Hansen, K.C.; Schedin, P. Quantitative extracellular matrix proteomics to study mammary and liver tissue microenvironments. Int. J. Biochem. Cell Biol. 2016, 81, 223-232. [CrossRef] [PubMed]

59. Brill, S. The role of fetal and adult hepatocyte extracellular matrix in the regulation of tissue-specific gene expression in fetal and adult hepatocytes. Eur. J. Cell Biol. 2002, 81, 43-50. [CrossRef]

60. Kim, T.H.; Mars, W.M.; Stolz, D.B.; Petersen, B.E.; Michalopoulos, G.K. Extracellular Matrix Remodeling at the Early Stages of Liver Regeneration in the Rat. Hepatology 1997, 26, 896-904. [CrossRef]

61. Nakai, S.; Shibata, I.; Shitamichi, T.; Yamaguchi, H.; Takagi, N.; Inoue, T.; Nakagawa, T.; Kiyokawa, J.; Wakabayashi, S.; Miyoshi, T.; et al. Collagen vitrigel promotes hepatocytic differentiation of induced pluripotent stem cells into functional hepatocyte-like cells. Biol. Open 2019, 8, bio042192. [CrossRef]

62. Azandeh, S.; Gharravi, A.M.; Orazizadeh, M.; Khodadi, A.; Tabar, M.H. Improvement of mesenchymal stem cell differentiation into the endoderm lineage by four step sequential method in biocompatible biomaterial. BioImpacts 2016, 6, 9-13. [CrossRef]

63. Maguire, T.; Novik, E.; Schloss, R.; Yarmush, M. Alginate-PLL microencapsulation: Effect on the differentiation of embryonic stem cells into hepatocytes. Biotechnol. Bioeng. 2006, 93, 581-591. [CrossRef]

64. Sun, J.; Tan, H. Alginate-Based Biomaterials for Regenerative Medicine Applications. Materials 2013, 6, 1285-1309. [CrossRef] [PubMed]

65. Yang, W.; Xia, R.; Zhang, Y.; Zhang, H.; Bai, L. Decellularized Liver Scaffold for Liver Regeneration. In Advanced Structural Safety Studies; Springer Science and Business Media LLC: Berlin, Germany, 2017; pp. 11-23.

66. Rana, D.; Zreiqat, H.; Benkirane-Jessel, N.; Ramakrishna, S.; Ramalingam, M. Development of decellularized scaffolds for stem cell-driven tissue engineering. J. Tissue Eng. Regen. Med. 2015, 11, 942-965. [CrossRef] [PubMed]

67. Wu, Q.; Tang, J.; Li, Y.; Li, L.; Wang, Y.; Bao, J.; Bu, H. Hepatic differentiation of mouse bone marrow-derived mesenchymal stem cells using a novel 3D culture system. Mol. Med. Rep. 2017, 16, 9473-9479. [CrossRef] [PubMed]

68. Jiang, W.-C.; Cheng, Y.-H.; Yen, M.-H.; Chang, Y.; Yang, V.W.; Lee, O.K. Cryo-chemical decellularization of the whole liver for mesenchymal stem cells-based functional hepatic tissue engineering. Biomaterials 2014, 35, 3607-3617. [CrossRef] [PubMed]

69. Navarro-Tableros, V.; Sanchez, M.B.H.; Figliolini, F.; Romagnoli, R.; Tetta, C.; Camussi, G. Recellularization of Rat Liver Scaffolds by Human Liver Stem Cells. Tissue Eng. Part A 2015, 21, 1929-1939. [CrossRef]

70. Wang, B.; Jakus, A.E.; Baptista, P.M.; Soker, S.; Soto-Gutierrez, A.; Abecassis, M.; Shah, R.N.; Wertheim, J.A. Functional Maturation of Induced Pluripotent Stem Cell Hepatocytes in Extracellular Matrix-A Comparative Analysis of Bioartificial Liver Microenvironments. STEM CELLS Transl. Med. 2016, 5, 1257-1267. [CrossRef]

71. Zhang, X.; Dong, J. Direct comparison of different coating matrix on the hepatic differentiation from adipose-derived stem cells. Biochem. Biophys. Res. Commun. 2015, 456, 938-944. [CrossRef]

72. Wang, B.; Li, W.; Dean, D.; Mishra, M.K.; Wekesa, K.S. Enhanced hepatogenic differentiation of bone marrow derived mesenchymal stem cells on liver ECM hydrogel. J. Biomed. Mater. Res. Part A 2017, 106, 829-838. [CrossRef]

73. Adamski, M.; Fontana, G.; Gershlak, J.R.; Gaudette, G.R.; Le, H.D.; Murphy, W.L. Two Methods for Decellularization of Plant Tissues for Tissue Engineering Applications. J. Vis. Exp. 2018, e57586. [CrossRef] [PubMed]

74. Aleahmad, F.; Talaei-Khozani, T.; Rajabi-Zeleti, S.; Sani, M.; Jalili-Firoozinezhad, S.; Bonakdar, S.; Heshmat-Azad, S.; Azarnia, M.; Jaberipour, M. Fabrication and Characterization of Heparin/Collagen Sponge for in Vitro Differentiation of Wharton's Jelly-Derived Mesenchymal Stem Cells into Hepatocytes. Zahedan J. Res. Med Sci. 2017, 17, 58724. [CrossRef]

75. Chitrangi, S.; Nair, P.; Khanna, A. Three-dimensional polymer scaffolds for enhanced differentiation of human mesenchymal stem cells to hepatocyte-like cells: A comparative study. J. Tissue Eng. Regen. Med. 2016, 11, 2359-2372. [CrossRef] [PubMed] 
76. Malinen, M.M.; Kanninen, L.; Corlu, A.; Isoniemi, H.M.; Lou, Y.-R.; Yliperttula, M.; Urtti, A. Differentiation of liver progenitor cell line to functional organotypic cultures in 3D nanofibrillar cellulose and hyaluronan-gelatin hydrogels. Biomaterials 2014, 35, 5110-5121. [CrossRef] [PubMed]

77. Abdulghani, S.; Mitchell, G.R. Biomaterials for In Situ Tissue Regeneration: A Review. Biomolecules 2019, 9, 750. [CrossRef] [PubMed]

78. Li, J.; Tao, R.; Wu, W.; Cao, H.; Xin, J.; Guo, J.; Jiang, L.; Gaoa, C.; Demetriou, A.A.; Farkas, D.L.; et al. 3D PLGA Scaffolds Improve Differentiation and Function of Bone Marrow Mesenchymal Stem Cell-Derived Hepatocytes. Stem Cells Dev. 2010, 19, 1427-1436. [CrossRef]

79. Wang, Y.; Lee, J.-H.; Shirahama, H.; Seo, J.; Glenn, J.S.; Cho, N.-J. Extracellular Matrix Functionalization and Huh-7.5 Cell Coculture Promote the Hepatic Differentiation of Human Adipose-Derived Mesenchymal Stem Cells in a 3D ICC Hydrogel Scaffold. ACS Biomater. Sci. Eng. 2016, 2, 2255-2265. [CrossRef]

80. Prowse, A.B.J.; Chong, F.; Gray, P.P.; Munro, T.P. Stem cell integrins: Implications for ex-vivo culture and cellular therapies. Stem Cell Res. 2011, 6, 1-12. [CrossRef]

81. Chan, H.F.; Zhang, Y.; Ho, Y.-P.; Chiu, Y.-L.; Jung, Y.; Leong, K.W. Rapid formation of multicellular spheroids in double-emulsion droplets with controllable microenvironment. Sci. Rep. 2013, 3, 3462. [CrossRef]

82. Janoštiak, R.; Pataki, A.C.; Brábek, J.; Rosel, D. Mechanosensors in integrin signaling: The emerging role of p130Cas. Eur. J. Cell Biol. 2014, 93, 445-454. [CrossRef]

83. Hwang, Y.; Goh, M.; Kim, M.; Tae, G. Injectable and detachable heparin-based hydrogel micropatches for hepatic differentiation of hADSCs and their liver targeted delivery. Biomaterials 2018, 165, 94-104. [CrossRef]

84. Mittal, N.; Tasnim, F.; Yue, C.; Qu, Y.; Phan, D.; Choudhury, Y.; Tan, M.-H.; Yu, H. Substrate Stiffness Modulates the Maturation of Human Pluripotent Stem-Cell-Derived Hepatocytes. ACS Biomater. Sci. Eng. 2016, 2, 1649-1657. [CrossRef]

85. Cozzolino, A.M.; Noce, V.; Battistelli, C.; Marchetti, A.; Grassi, G.; Cicchini, C.; Tripodi, M.; Amicone, L. Modulating the Substrate Stiffness to Manipulate Differentiation of Resident Liver Stem Cells and to Improve the Differentiation State of Hepatocytes. Stem Cells Int. 2016, 2016, 1-12. [CrossRef] [PubMed]

86. You, J.; Park, S.-A.; Shin, D.-S.; Patel, D.; Raghunathan, V.K.; Kim, M.; Murphy, C.J.; Tae, G.; Revzin, A. Characterizing the Effects of Heparin Gel Stiffness on Function of Primary Hepatocytes. Tissue Eng. Part A 2013, 19, 2655-2663. [CrossRef]

87. Lee, H.-J.; Son, M.J.; Ahn, J.; Oh, S.J.; Lee, M.; Kim, A.; Jeung, Y.-J.; Kim, H.-G.; Won, M.; Lim, J.H.; et al. Elasticity-based development of functionally enhanced multicellular 3D liver encapsulated in hybrid hydrogel. Acta Biomater. 2017, 64, 67-79. [CrossRef] [PubMed]

88. Rajendran, D.; Hussain, A.; Yip, D.; Parekh, A.; Shrirao, A.; Cho, C.H. Long-term liver-specific functions of hepatocytes in electrospun chitosan nanofiber scaffolds coated with fibronectin. J. Biomed. Mater. Res. Part A 2017, 105, 2119-2128. [CrossRef]

89. Bishi, D.K.; Mathapati, S.; Venugopal, J.R.; Guhathakurta, S.; Cherian, K.M.; Ramakrishna, S.; Verma, R.S. Trans-Differentiation of Human Mesenchymal Stem Cells Generates Functional Hepatospheres on Poly(L-Lactic Acid)-Co-Poly(Epsilon-Caprolactone)/Collagen Nanofibrous Scaffolds. J. Mater. Chem. B 2013, 1, 3972-3984. [CrossRef]

90. Asonuma, K.; Gilbert, J.C.; Stein, J.E.; Takeda, T.; Vacanti, J.P. Quantitation of transplanted hepatic mass necessary to cure the gunn rat model of hyperbilirubinemia. J. Pediatr. Surg. 1992, 27, 298-301. [CrossRef]

91. Ranucci, C.S.; Kumar, A.; Batra, S.P.; Moghe, P.V. Control of hepatocyte function on collagen foams: Sizing matrix pores toward selective induction of 2-D and 3-D cellular morphogenesis. Biomaterials 2000, 21, 783-793. [CrossRef]

92. Wang, X.; Ding, B.; Li, B. Biomimetic electrospun nanofibrous structures for tissue engineering. Mater. Today 2013, 16, 229-241. [CrossRef]

93. Andalib, M.N.; Lee, J.S.; Ha, L.; Dzenis, Y.A.; Lim, J.Y. Focal adhesion kinase regulation in stem cell alignment and spreading on nanofibers. Biochem. Biophys. Res. Commun. 2016, 473, 920-925. [CrossRef] [PubMed]

94. Cooper, A.; Leung, M.; Zhang, M. Polymeric Fibrous Matrices for Substrate-Mediated Human Embryonic Stem Cell Lineage Differentiation. Macromol. Biosci. 2012, 12, 882-892. [CrossRef] [PubMed]

95. Morgan, K.; Bryans, A.; Brzeszczynski, F.; Samuel, M.K.; Treskes, P.; Brzeszczynska, J.; Morley, S.; Hayes, P.; Gadegaard, N.; Nelson, L.; et al. Oxygen plasma substrate and specific nanopattern promote early differentiation of HepaRG progenitors. Tissue Eng. Part A 2020. [CrossRef] [PubMed] 
96. Duval, K.E.A.; Grover, H.; Han, L.-H.; Mou, Y.; Pegoraro, A.F.; Fredberg, J.; Chen, Z. Modeling Physiological Events in 2D vs. 3D Cell Culture. Physiology 2017, 32, 266-277. [CrossRef]

97. Chan, H.F.; Zhang, Y.; Leong, K.W. Efficient One-Step Production of Microencapsulated Hepatocyte Spheroids with Enhanced Functions. Small 2016, 12, 2720-2730. [CrossRef]

98. Bratt-Leal, A.M.; Carpenedo, R.L.; McDevitt, T.C. Engineering the embryoid body microenvironment to direct embryonic stem cell differentiation. Biotechnol. Prog. 2009, 25, 43-51. [CrossRef]

99. Richardson, T.; Kumta, P.N.; Banerjee, I. Alginate Encapsulation of Human Embryonic Stem Cells to Enhance Directed Differentiation to Pancreatic Islet-Like Cells. Tissue Eng. Part A 2014, 20, 3198-3211. [CrossRef]

100. Hong, H.; Stegemann, J.P. 2D and 3D collagen and fibrin biopolymers promote specific ECM and integrin gene expression by vascular smooth muscle cells. J. Biomater. Sci. Polym. Ed. 2008, 19, 1279-1293. [CrossRef]

101. McClelland, R.; Wauthier, E.; Uronis, J.; Reid, L. Gradients in the Liver's Extracellular Matrix Chemistry from Periportal to Pericentral Zones: Influence on Human Hepatic Progenitors. Tissue Eng. Part A 2008, 14, 59-70. [CrossRef]

102. Doddapaneni, R.; Chawla, Y.K.; Das, A.; Kalra, J.K.; Ghosh, S.; Chakraborti, A. Overexpression of microRNA-122 enhances in vitro hepatic differentiation of fetal liver-derived stem/progenitor cells. J. Cell. Biochem. 2013, 114, 1575-1583. [CrossRef]

103. Jung, K.H.; McCarthy, R.L.; Zhou, C.; Uprety, N.; Barton, M.C.; Beretta, L. MicroRNA Regulates Hepatocytic Differentiation of Progenitor Cells by Targeting YAP1. Stem Cells 2016, 34, 1284-1296. [CrossRef] [PubMed]

104. Liu, T.; Zhang, S.; Xiang, D.; Wang, Y. Induction of Hepatocyte-Like Cells from Mouse Embryonic Stem Cells by Lentivirus-Mediated Constitutive Expression of Foxa2/Hnf4a. J. Cell Biochem. 2013, 114, 2531-2541. [CrossRef] [PubMed]

(C) 2020 by the authors. Licensee MDPI, Basel, Switzerland. This article is an open access article distributed under the terms and conditions of the Creative Commons Attribution (CC BY) license (http://creativecommons.org/licenses/by/4.0/). 